\title{
Peningkatan Pemahaman Konsep Geometri melalui Tahapan Berpikir Van Hiele di SMP Negeri 8 Langsa
}

\author{
Putri Novita Sari ${ }^{1}$; Srimuliati ${ }^{2}$ \\ ${ }_{1}^{1}$ Mahasiswa Pendidikan Matematika FTIK IAIN Langsa \\ ${ }^{2}$ Dosen Pendidikan Matematika FTIK IAIN Langsa \\ Pns98504@gmail.com. srimuliatimpd@gmail.com
}

\begin{abstract}
Understanding the concept is a benchmark student can proceed to the next stage in the learning process. Van Hiele's thinking stage is a solution to direct students to the actual concept of geometry. The purpose of this study was to determine whether there was an increase in understanding of the geometrical concepts of eighth-grade students of SMPN 8 Langsa through Van Hiele thinking stages. This study used a One Group Pretest-Posttest Design research design. With a population of all eighth-grade students of SMPN 8 Langsa, the sample was selected using a simple random sampling technique, namely grade VIII1 students. The instrument uses the ability to understand the ability of geometric concepts in the form of a description consisting of 6 questions. The results of the calculation of the percentage of students understanding the concept of geometry show an increase of 48\%. The results of data analysis obtained that count $>t_{\text {table }}$ is $12.59>2.08$, this means that Ho is rejected and $\mathrm{Ha}$ is accepted, so the conclusion obtained is that there is an increase in understanding of students' geometry concepts through the stages of van hiele thinking at SMPN 8 Langsa.
\end{abstract}

Keywords: Geometry, Understand mathematical concepts, and Stages of thinking about Van Hiele.

\begin{abstract}
Abstrak
Pemahaman konsep adalah tolak ukur siswa dapat melanjutkan ke tahapan lanjutan dalam proses pembelajaran. Tahapan berfikir Van Hiele merupakan suatu solusi untuk mengarahkan siswa pada konsep geometri yang sebenarnya. Tujuan penelitian ini adalah untuk mengetahui apakah terdapat peningkatan pemahaman konsep geometri siswa kelas VIII SMPN 8 Langsa melalui tahapan berfikir Van Hiele.Penelitian ini menggunakan rancangan penelitian One Group Pretest-Posttest Desaign. Dengan populasi seluruh siswa kelas VIII SMPN 8 Langsa, sampel terpilih menggunakan tehnik simple random samplingyaitu siswa kelas VIII. Instrumen menggunakan tes kemampuan pemahaman konsep geometri berbentuk uraian yang terdiri dari 6 soal. Dari hasil perhitungan persentase pemahaman konsep geometri siswa menunjukan peningkatan sebesar 48\%. Hasil analisis data diperoleh bahwat hitung $>t_{\text {tabel }}$ yaitu 12,59> 2.08, hal ini berarti Ho ditolak dan Ha diterima, sehingga kesimpulan yang diperoleh yaitu terdapat peningkatan pemahaman konsep geometri siswa melalui tahapan berfikir van hiele di SMPN 8 Langsa.
\end{abstract}

Kata Kunci: Geometri, Pemahaman Konsep Matematika, dan Tahapan Berfikir Van Hiele. 


\section{A. Pendahuluan}

Geometri merupakan salah satu cabang dari ilmu matematika. Belajar geometri berarti mempelajari tentang bentuk ruang, komposisi beserta sifatsifatnya, ukuran-ukurannya dan hubungan antara yang satu dengan yang lain. Halim dan Abdul menyebutkan dua tujuan geometri dipelajari, yaitu mengembangkan logikakemampuan berpikir kritis dan mengembangkan intuisi spasial yang mengacupada bagaimana satu ruang pandangan dan daerah di dunia nyata(Halim \& Abdul, 2013).Kaitannya dengan kehidupan sehari hari begitu erat dalam geometri misalnya dengan bangun ruang dan benda-benda yang ada di sekitar. Dan pada dasarnya geometri mempunyai peluang yang lebih besar untuk dipelajari siswa dibandingkan dengan cabang matematika yang lain karena geometri juga dapat diterapkan di cabangcabang lain matematika. Misalnya, geometri diterapkan dalam mata pelajaran lain seperti gambar teknik, geometri menggambar dan sebagainya.

Namun dalam beberapa tahun terakhir, materi geometri kurang begitu berkembang. Madja mengemukakan bahwa hasil belajar geometri siswa baik geometri dasar di SMP maupun lanjutan di SMA, kurang memuaskan jika dibandingkan dengan materi matematika lainnya (Abdussakir, 2010). Siswa mengalami kesulitan dalam memahami konsep geometri terutama dalam konsep keruangan. Hal ini dikarenakan beberapapenyebab di antaranya seperti disebutkan oleh Khotimah dalam penelitiannya yaitu keterampilan siswa dalam menggambar bangun-bangun ruang dimensi tiga masih tergolong rendah,kemampuan pemahaman konsep matematika siswa masih juga kurang, dan sebagian siswa hanya mengandalkan hafalan tanpa memahami konsep sehingga membuat kesalahan dalam menyelesaikan latihan, serta materi prasyarat yaitu dasar dasar geometri belum dikuasai oleh sebagian siswa(Khotimah, 2013).

Berbicara geometri tentunya akan adil jika mengikutsertakan Van Hiele. Van Hiele merupakan seorang tokoh yang mengkhususkan dirinya dalam teori -teori berfikir demi kelangsungan pembelajaran geometri yang selanjutnya dikenal dengan tahapan berfikir Van Hiele. Didalam tahapan berfikir Van Hiele, mempelajari geometri disebut memiliki tiga unsur utama 
yaitu waktu, materi pengajaran, dan metode pengajaran yang digunakan. Jika ketiga unsur ditata secara terpadu, akan dapat meningkatkan kemampuan berpikir siswa kepada tahapan berpikir yang lebih tinggi.

Tahapan berfikir Van Hiele merupakan solusi yang baik untuk mengarahkan siswa pada konsep geometri yang sebenarnya. Tahapan berfikir Van Hiele lebih menekankan pada pemahaman konsep, dikarenakan materi yang dijelaskan yaitu geometri bersifat abstrak. Dan hal ini diperkuat oleh penelitian terdahulu yang mengatakan bahwa untuk meningkatkan pemahaman konsep geometri siswa dapat ditingkatkan salah satunya melalui pembelajaran dengan tahapan berfikir Van Hiele (Epon, 2010).

Menurut salah satu guru matematika di SMP Negeri 8 Langsa ditemukan fakta bahwa guru sering merasa bingung mengapa siswa saat diberi penjelasan tentang materi yang dianggap masih level rendah saja siswa sudah tidak memahaminya sehingga menyebabkan hasil belajar geometri siswa sangat jauh dari KKM. Ternyata yang menyebabkan itu adalah kemampuan pemahaman konsep matematika siswa masih kurang.

Dalam bermatematika dikenal istilah heirarki. Artinya, mempelajari matematika harus secara bertahap dimulai dari tahapan dasar, menengah hingga lanjutan. Dalam mempelajari geometri, Van Hiele menyebutkan, seorang siswa yang berada pada tingkat berfikir yang lebih rendah tidak mungkin dapat mengerti atau memahami materi yang berada pada tingkat yang lebih tinggi. Pemikiran ini senada dengan apa yang disebut bahwa bermatematika adalah berjenjang. Andaipun siswa dipaksa untuk memahaminya, seorang siswa baru bisa sampai pada tahap hafalan saja bukan melalui pengertian. Untuk mendapatkan hasil yang diharapkan yaitu siswa memahami geometri dengan konsep, kegiatan belajar mengajar siswa harus disesuaikan dengan tingkat perkembangan diri siswa atau disesuaikan dengan tahap kemampuan berpikirnya. Dengan demikian siswa dapat memperkaya pengalaman dan berpikirnya.

Salah satu aspek yang fundamental dalam belajar adalah pemahaman itu sendiri. Dan setiap membelajarkan matematika seharusnya lebih memfokuskan untuk menanamkan konsep berdasarkan pemahaman. 
Pemahaman dimaknai sebagai kemampuan untuk menjelaskan suatu situasi/keadaan atau suatu tindakan. Dan konsep merupakan suatu kategori stimuli yang memiliki ciri-ciri umum. Jadi, pemahaman konsepadalah kemampuan untuk memberi artiatau menjelaskan suatu konsep atau kategori stimuli yang memiliki ciri-ciri umum. Sedangkan pemahaman konsep matematika merupakan suatu kemampuan untuk menerangkan/menjelaskan dan memberi arti/makna pada konsep-konsep atau kategori matematika (Huzaifah, 2011).

Dalam mempelajari matematika, sudah seharusnya pemahaman ditanamkan kepada setiap siswa. Tanpa pemahaman, siswa tidak akan mampu mengaplikasikan prosedur, konsep, ataupun proses. Matematika akan dimengerti dan dipahami oleh siswa bila dalam proses belajarnya terjadi keterkaitan antara informasi yang baru diperoleh dengan informasi yang ada sebelumnya dalam diri siswa. Kemampuan mengkonstruksi makna dari pesan-pesan pembelajaran, baik yang bersifat lisan, tulisan ataupun grafis itulah yang disebut memahami.

Kepahaman siswa terhadap suatu hal/kejadian/masalah dapat dilihat melalui ciri-ciri berikut, yaitu: dapat menjelaskan kembali suatu hal tersebut, dapat menggunakan hal yang dilaluinya dalam situasi lain, serta menyelesaikan latihan soal (Khoiri, 2014). Senada dengan pernyataan dari Badan Standar Nasional Pendidikan tentang indikator pemahaman konsep. Seorang siswa dikatakan paham terhadap suatu konsep jika mampu :1) menyatakan ulang suatu konsep, 2) mengklarifikasikan objek menurut sifat/ciri tertentu, 3) memberi contoh dan bukan contoh dari suatu persoalan, 4) menyajikan konsep dalam berbagai bentuk representasi matematika, dan 5) mengembangkan syarat perlu dan syarat cukup suatu konsep.

Van Hiele (Riati, 2014) menyatakan bahwa pembelajaran geometri hanya efektif apabila sesuai dengan tahapan berfikir siswa. Hasil belajar dapat diproses melalui 5 tahap, yang sekaligus sebagai tujuan pembelajaran. kelima tahapan pembelajaran tersebut yaitu informasi, orientasi terarah, uraian, orientasi bebas, dan integrasi. Penelitian Van Hiele terhadap tahapan 
berfikir anak dalam memahami geometri melahirkan beberapa kesimpulan. Van Hiele menyatakan bahwa terdapat 5 tahap pemahaman geometri yaitu:

1. Tahap Pengenalan; Pada tahap ini siswa hanya baru mengenal bangunbangun geometri seperti bola, kubus, segitiga, persegi dan bangunbangun geometri lainnya melalui benda nyata maupun alat peraga.

2. Tahap Analisis; Bila pada tahap pengenalan, anak belum mengenal sifatsifat dari bangun geometri. Tidak demikian pada tahap Analisis. Pada tahap ini anak sudah dapat memahami sifat-sifat dari bangun-bangun geometri.

3. Tahap Pengurutan; Pada tahap ini anak sudah mampu mengetahui hubungan yang terkait antara suatu bangun geometri dengan bangun geometri lainnya.

4. Tahap Deduksi; Pada tahap ini anak sudah dapat memahami deduksi, yaitu mengambil kesimpulan secara deduktif.

5. Tahap Keakuratan; Tahap terakhir dari perkembangan kognitif anak dalam memahami geometri adalah tahap keakuratan. Pada tahap ini anak sudah memahami betapa pentingnya ketepatan dari prinsip-prinsip dasar yang melandasi suatu pembuktian.

Tahapan berfikir Van Hiele yang digunakan peneliti adalah mulai dari tahap 1 sampai tahap 3 saja karena berdasarkan observasi diketahui bahwa tahap berfikir anak dilapangan masih tergolong menengah ke bawah sehingga akan sulit untuk anak mencapai tahap yang lebih tinggi yaitu tahap deduksi dan tahap akurasi.

\section{B. Metode}

Penelitian ini digolongkan ke dalam penelitian quasi eksperimen. Menggunakan rancangan penelitian One Group Pretest-Posttest Desaign (Sugiyono, 2010), desain penelitian ini dapat digambarkan sebagai berikut:

\section{$\mathbf{O}_{1} \times \mathbf{O}_{2}$}

Dilaksanakan di SMP Negeri 8 Langsa dengan populasi seluruh siswa kelas VIII. Menggunakan tehnik simple random sampling (Sugiyono, 2010), 
terpilih kelas Sampel VIII 1 sebagai kelas penelitian. Bertujuan untuk meningkatkan pemahaman konsep siswa dalam belajar geometri berdasarkan teori Van Hiele. Instrumen menggunakan tes kemampuan pemahaman konsep berbentuk uraian sebanyak 6 soal. Tes pemahaman konsep diberikan sebelum dan sesudah pembelajaran.

\section{Hasil dan Pembahasan}

\section{a. Analisis Deskriptif Kemampuan Awal Siswa}

Tes kemampuan awal dilaksanakan sebelum dilakukan perlakuan pada materi prisma dan limas. Perhitungan data secara lengkap dari hasil pretest diperoleh nilai rata-rata dari siswa yang berjumlah 22 adalah 50,5, ini menunjukkan bahwa sebelum dilakukan perlakuan tahapan berfikir Van Hiele pada materi prisma dan limas rata-rata siswa masih tergolong kurang baik. Standar deviasi sebelum dilakukan perlakuan tahapan berfikir Van Hiele adalah 7,4 dengan nilai siswa yang sangat beragam, dengan nilai maksimum 64 dan nilai minimumnya 40. Ini membuktikan bahwa pemahaman konsep siswa pada materi prisma dan limas masih kurang memuaskan yang mengakibatkan nilai siswa masih tegolong rendah dan sangat perlu dilakukan perbaikan.

\section{b. Analisis Deskriptif Kemampuan Akhir Siswa}

Setelah dilakukan postest didapatkan data siswa dengan perlakuan tahapan berfikir Van Hiele pada materi prisma dan limas. diperoleh nilai rata-rata dari siswa yang berjumlah 22 adalah 74.9, ini menunjukkan bahwa setelah dilakukan perlakuan tahapan berfikir Van Hiele pada materi prisma dan limas rata-rata siswa sudah baik. Standar deviasi setelah dilakukan perlakuan tahapan berfikir Van Hiele adalah 7,9 dengan nilai siswa yang sangat beragam, dengan nilai maksimum 85 dan nilai minimumnya 50. Ini membuktikan bahwa pemahaman konsep siswa pada materi prisma dan limas cukup memuaskan. 
Berdasarkan pembahasan nilai siswa di atas terlihat bahwa sebelum dilakukan perlakuan tahapan berfikir Van Hiele pada materi prisma dan limas bahwa rata-rata dari siswa yang berjumlah 22 adalah 50,5, sedangkan setelah dilakukan perlakuan tahapan berfikir Van Hiele pada materi prisma dan limas adalah 74.9 ini berarti pemahaman konsep siswa meningkat, demikian juga standar deviasinya dari 7,4 meningkat menjadi 7,9. Nilai maksimum pada tahap pretest adalah 64 dan pada tahap postest nilai maksimum meningkat menjadi 85 sedangkan nilai minimum pada tahap pretest 40 tetapi pada tahap postest nilai minimum menjadi 50. Jadi, dapat disimpulkan bahwa pemahaman konsep siswa pada materi prisma dan limas setelah postest mengalami peningkatan.

\section{Uji Normalitas}

Berikut ditampilkan hasil perhitungan uji normalitas data pretest dan posttest pada tabel 1 dibawah ini:

\section{Tabel 1 Hasil Uji Normalitas Data Pretest dan Posttest menggunakan Liliefors}

\begin{tabular}{|c|c|c|c|c|}
\hline Analisis & $\mathbf{N}$ & lhitung & ltabel & Keterangan \\
\hline Pretest & 22 & 0,1642 & 0,184 & Normal \\
\hline Posttest & 22 & 0,1023 & 0,184 & Normal \\
\hline
\end{tabular}

Dari tabel 1 di atas menunjukkan bahwa taraf $(\propto)=0,05$ diperoleh $l_{\text {hitung }}<l_{\text {tabel, }}$, sehingga disimpulkan data hasil pretest dan posttest berdistribusi normal. Ini menunjukkan bahwa uji persyaratan pada penelitian ini dapat dilanjutkan. Hasil perhitungan uji gain disajikan pada tabel 2 dibawah ini:

Tabel 2 Hasil Rekapitulasi Uji Gain

\begin{tabular}{|c|c|c|c|c|c|}
\hline $\begin{array}{c}\text { Yang } \\
\text { Dihitung }\end{array}$ & $\begin{array}{c}\text { Nilai } \\
\text { Pretest }\end{array}$ & $\begin{array}{c}\text { Nilai } \\
\text { Postest }\end{array}$ & Gain & $\begin{array}{c}\text { Indeks } \\
\text { Gain }\end{array}$ & Kriteria \\
\hline Jumlah & 104 & 120 & 16 & 0,4 & Rendah \\
\hline Rata-rata & 52 & 60 & 8 & 0,2 & \\
\hline \multicolumn{7}{|r|}{}
\end{tabular}




\begin{tabular}{|c|c|c|c|c|c|}
\hline Jumlah & 1008 & 1527 & 519 & 10,5 & \multirow{2}{*}{ Sedang } \\
\cline { 1 - 5 } Rata-rata & 50,4 & 76,3 & 25,9 & 0,5 & \\
\hline
\end{tabular}

Berdasarkan tabel 2 uji gain dapat dilihat bahwa pemahaman konsep geometri siswa mengalami peningkatan. Hasil data nilai siswa melalui tahapan berfikir Van Hiele menunjukan hasil yang baik, hal ini dibuktikan dengan indeks gain yang diperoleh dari 22 siswa 2 siswa yang mengalami peningkatan kriteria rendah selebihnya 20 siswa yang lain mengalami peningkatan kriteria sedang. Ini menunjukan pemahaman konsep geometri siswa sudah tergolong baik.

\section{Persentase Peningkatan Pemahaman Konsep Geometri}

Berdasarkan hasil perhitungan persentase pemahaman konsep geometri siswa menunjukan peningkatan sebesar $48 \%$ setelah dilakukan perlakuan tahapan berfikir Van Hiele pada materi prisma dan limas. Setelah dianalisis ternyata nilai t hitung adalah 12,59 . Hal ini dapat dikatakan bahwa $12,59>2.08$ yaitu $t_{\text {hitung }}>t_{\text {tabel }}$, hal ini berarti bahwa Ho ditolak dan mengakibatkan Ha diterima, sehingga dapat disimpulkan bahwa terdapat peningkatan pemahaman konsep geometri melalui tahapan berfikir van hiele di SMP Negeri 8 Langsa.

Tinggi rendahnya keberhasilan belajar siswa salah satunya dipengaruhi dari pemahaman konsep siswa. Rendahnya pemahaman konsep matematika khususnya geometri dikarenakan 4 faktor utama yaitu keterampilan siswa dalam menggambar bangun-bangun ruang dimensi tiga masih tergolong rendah, kemampuan pemahaman konsep matematika siswa masih juga kurang, dan sebagian siswa hanya mengandalkan hafalan tanpa memahami konsep sehingga membuat kesalahan dalam menyelesaikan latihan, serta materi prasyarat yaitu dasar dasar geometri belum dikuasai oleh sebagian siswa. Dalam hal ini dhendaknya guru harus lebih selektif dalam memilih strategi pembelajaran yang sesuai dengan tahapan berfikir siswa. 
Berdasarkan data yang telah diperiksa dan dianalisis, maka dapat dinyatakan bahwa pemahaman konsep geometri siswa melalui tahapan berfikir van hiele dikategorikan cukup baik dengan nilai rata-rata 74.9 dari 50.5. Kemudian perhitungan persentase pemahaman konsep geometri siswa menunjukan peningkatan sebesar 48\%setelah dilakukan perlakuan tahapan berfikir Van Hiele pada materi prisma dan limas. Berdasarkan analisis data menggunakan uji-t yang diketahui $t_{\text {hitung }}=12,59$ dan $t_{\text {tabel }}=0,08$. Hasil perhitungan tersebut menunjukkan bahwa thitung $>t_{\text {tabel, }}$ sehingga hasil penelitian adalah Ha diterima dan $\mathrm{HO}$ ditolak, yaitu terdapat peningkatan pemahaman konsep geometri melalui tahapan berfikir Van Hiele di SMP Negeri 8 Langsa.

Siswa mendapatkan nilai posttest yang lebih tinggi daripada pretest. Siswa mampu menyelesaikan setiap butir soal materi prisma dan limas yang diberikan penulis dengan baik hal ini dikarenakan tahapan berfikir yang digunakan sesuai dengan tahapan berfikir siswa. Dan dalam pembelajaran ini siswa diberi kesempatan untuk lebih aktif dan diberi kebebasan untuk berfikir menyelesaikan soal sesuai dengan tahapan berfikir yang mereka miliki. Dengan demikian pembelajaran yang diberikan akan tersampaikan secara optimal kepada siswa. Alasan lain terjadinya peningkatan pemahaman konsep dikarenakan siswa terus berlatih tahap demi tahap menyelesaiakan soal yang ada. Jadi dapat disimpulkan bahwa setelah terjadinya proses belajar maka hasil belajar siswa juga mengalami suatu peningkatan ke taraf yang lebih baik.

Siswa melakukan aktivitasnya dalam pembelajaran tersebut sesuai dengan rencana pelaksanaan pembelajaran yang telah dibuat oleh guru. Pembelajaran dilakukan dengan dua kali pertemuan. Pada pertemuan pertama siswa belum mampu menyatakan ulang konsep materi prisma dan limas, memberikan contoh dan bukan contoh, apalagi menyelesaikan soal materi prisma dan limas. Namun ketika peneliti menggunakan tahapan berfikir Van Hiele siswa mulai bersemangat dan mengikuti pembelajaran yang sedang berlangsung walaupun masih ada sebagian siswa yang belum peduli. Selanjutnya pada pertemuan kedua siswa lebih baik dari pertemuan 
sebelumnya. Ketika peneliti menggunakan tahapan berfikir Van Hiele seluruh siswa perhatiannya sudah fokus. Siswa mulai merasa senang dalam mengikuti pembelajaran dan jawaban siswa bervariasi dalam mengerjakan soal serta perubahan sangat baik dari pertemuan pertama ke pertemuan kedua memberikan suatu pembuktian tahapan berfikir Van Hiele membuat pembelajaran siswa menjadi lebih efektif dan efisien. Dari uraian di atas dapat disimpulkan bahwa ada peningkatan pemahaman konsep geometri melalui tahapan berfikir Van Hiele di SMP Negeri 8 Langsa

\section{Kesimpulan}

Dari hasil perhitungan persentase pemahaman konsep geometri siswa menunjukan peningkatan sebesar 48\%. Dan dari hasil analisis data diperoleh hasil bahwa12,59>0.08 yaitu $t_{\text {hitung }}>t_{\text {tabel }}$, hal ini berarti Ha diterima dan Ho ditolak, sehingga dapat disimpulkan bahwa terdapat peningkatan pemahaman konsep geometri melalui tahapan berfikir Van hHele di SMP Negeri 8 Langsa. Berdasarkan pemaparan dan hasil penelitian, maka peneliti menyarankan beberapa hal sebagai berikut dalam proses pembelajaran hendaknya guru melibatkan siswa untuk berperan aktif, sebelum menentukan strategi yang baik dalam pembelajaran guru harus mengenali karakteristik atau tahapan berfikir siswa terlebih dahulu, dan penerapan tahapan berfikir van hiele dapat dijadikan referensi bagi guru guna meningkatkan pemahaman konsep siswa.

\section{DAFTAR PUSTAKA}

Abdussakir. (2010). Pembelajaran Geometri Sesuai Teori Van Hiele. Jurnal Kependidikan dan Keagamaan 7 (2) , hlm. 1-9.

Epon, N. (2010). Pengembangan Kemampuan Komunikasi Geometris Siswa Sekolah Dasar Melalui Pembelajaran Berbasis Teori Van Hiele. Jurnal Saung Guru, Vol. I No. 2. , hlm. 28 - 34.

Halim, \& Abdul, d. (2013). The Effects of Van Hiele's Phases of Learning Geometry on Students' Degree of Acquisition of Van Hiele Levels. Procedia-Social and Behavioral Sciences 102. 
Huzaifah, E. (2011). Upaya Meningkatkan Pemahaman Konsep Geometri Siswa Dengan Menggunakan Teori Van Hiele. Skripsi, Universitas Islam Negeri Syarif Hidayatullah Jakarta .

Khoiri, M. (2014). Pemahaman Siswa Pada Konsep Segiempat Berdasarkan Teori Van Hiele. Prosiding Seminar Nasional Matematika. Jember: Universitas Jember.

Khotimah, H. (2013). Meningkatkan Hasil Belajar Geometri Dengan Toeri Van Hiele . Prosiding Seminar Nasional Matematika, UNY. Yogyakarta: G-2 PROSIDING ISBN : 978 - 979 - $16353-9-4$.

Riati, M. (2014). Teori Belajar Van Hiele. Dipetik 5 8, 2016, dari https://www.academia

Sugiyono. (2010). Metode Penelitian Pendidikan. Bandung: Alfabeta. 
